\title{
The impact of exploitation and environmental factors on the degradation of steel road safety equipment
}

\author{
Joanna Kobus ${ }^{1,{ }^{*}}$, Lech Kwiatkowski ${ }^{1}$, and Rafat Lutze ${ }^{1}$ \\ ${ }^{1}$ Institute of Precision Mechanics, Department of Corrosion\&Anticorrosion Technologies, 3 \\ Duchnicka St.01-796 Warsaw, Poland.
}

\begin{abstract}
The work is aimed at determining the corrosivity of atmosphere in the vicinity of roads, taking into account the characteristics of local emission sources, including traffic intensity of vehicles along with climatic and exploitation factors. Determination of the corrosivity of atmosphere was carried out according to the procedures described in PN EN ISO standards. Samples for testing were made of low carbon steel DC05, zinc and hot dip galvanized steel. Samples were assembled at 19 sites in the close vicinity of roads and highways near the measurement points of vehicle traffic intensity. The mass loss of exposed samples was the basis for determination the atmosphere corrosivity at each of 19 test sites. Regarding steel, the corrosivity category of $\mathrm{C} 4$ was observed at $8 / 19$ sites. Corrosion losses outside roads are 2-4 times lower and ranged within the categories of $\mathrm{C} 2$ and $\mathrm{C} 3$. Zinc corrosion losses classified to category $\mathrm{C} 4$ occurred at $2 / 19$ stations. In the remaining ones they corresponded to category $\mathrm{C} 3$. In areas outside of roads, zinc corrosion losses are about $20-100 \%$ lower (C2). The first attempts to model the dependence of operating and environmental parameters on zinc and zinc coating corrosion losses indicate significant correlation between zinc and zinc coating corrosion losses as a function
\end{abstract}

\section{Introduction}

The environment created around the road area differs significantly in its qualitative and quantitative composition from areas even slightly distant from sources of road emissions [1]. Vehicles emit a gas mixture, which within a fraction of a second, creates various substances with strong corrosive properties: nitrogen oxides, nitric acid, sulfur dioxide, ozone, reactive radicals, soot, organic acids and others [2]. There is no available information on the relationship between the rate of corrosion of metals assembled in the construction of road infrastructure, and environmental parameters including vehicle traffic and/or other exploitation conditions. The work is aimed at the determining of corrosivity of atmosphere in the vicinity of selected roads, taking into account the characteristics of local emission sources, including traffic intensity of vehicles along with climatic and exploitation factors. The data obtained will be used to develop methods for predicting the rate of corrosion of

\footnotetext{
* Corresponding author: asia@imp.edu.pl
} 
metals and atmospheric corrosivity categories in selected areas with specific emission characteristics related to roads and highways.

\section{Method}

Determination of the corrosivity of atmosphere was carried out according to procedures described in PN EN ISO standards [3-6]. Samples for testing with dimensions of $150 \times 100$ x $1 \mathrm{~mm}$ were made of low carbon steel DC05, zinc and hot dip galvanized steel. Samples were assembled at 19 sites in the close vicinity of roads and highways and monitored within the period of 07.2017-10.2018. These places are located near the measurement points/stations of vehicle traffic intensity carried out by GDDKiA. For stations with automatic measurement of pollution (Katowice, Kraków, Warszawa/Niepodległości Avenue), data came from the network of Regional Inspectorates for Environmental Protection (www.wios.katowice.gov.pl, www.wios.krakow.gov.pl, www.wios.warszawa.gow.pl).

In other cases the following parameters were monitored directly at corrosion sites: concentration of $\mathrm{NO}_{2}$ and $\mathrm{SO}_{2}$ by means of passive samples [7], deposition of chlorides and sulphates according to [5]. An average annual traffic volume divided by a type of vehicle is shown in Fig. 1.

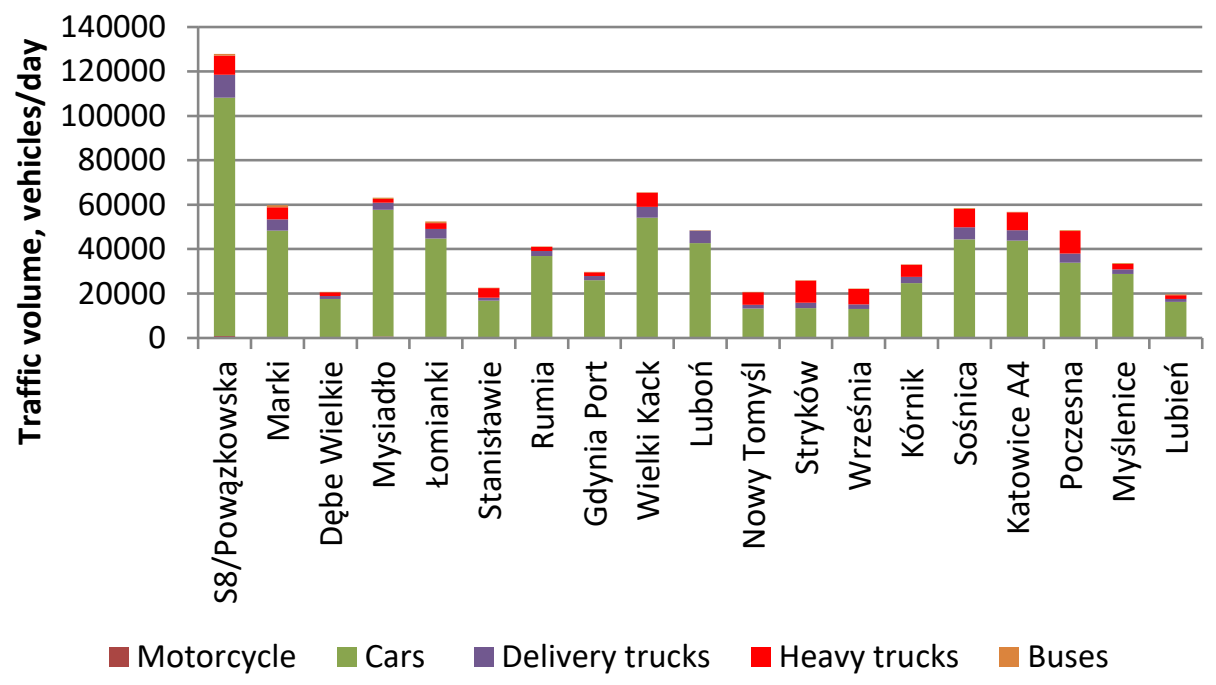

Fig. 1. An average annual traffic intensity at corrosion sites.

The average annual traffic intensity at corrosion sites ranged from 19599 vehicles/day to 127822 vehicles/day. Passenger cars and microbuses accounted for 90\% (Mysiadło) to 54\% (Stryków) of the total number of vehicles.

\section{Results and discussion}

The first set of results contain an evaluation of corrosive agents on site. An average concentration of $\mathrm{NO}_{2}$ related to traffic intensity emitted by vehicles at corrosion sites is illustrated in Fig. 2. 




Road Background

Fig. 2. An average $\mathrm{NO}_{2}$ concentration during 1 year exposition at corrosion sites.

Emission of $\mathrm{NO}_{2}$ within annual period of exposition ranged from $81 \mu \mathrm{g} / \mathrm{m}^{3}$ at the stand in Warsaw S8/Powązkowska to $34 \mu \mathrm{g} / \mathrm{m}^{3}$ at the position of Gdynia Port. Maximum concentrations of $\mathrm{NO}_{2}$ equal to $115 \mu \mathrm{g} / \mathrm{m}^{3}$ were observed in the winter period at the stand in Warsaw S8/ Powązkowska. $\mathrm{NO}_{2}$ concentrations recorded outside the area of direct impact of traffic pollution, e.g. at the urban background stations, are 2-3 times lower than on the roads (see selected background level in Fig. 2).

Chloride ions also belong to the list of common corrosion agents. In the case of roads and highways direct corrosion risk results from the application of de-icing salts during a winter period. An average $\mathrm{Cl}^{-}$ions deposition within an exposition period is shown in Fig. 3 .



Fig. 3. An average $\mathrm{Cl}^{-}$ions deposition within exposition period. 
According to GDDKiA data, at selected test sites, de-icing salt was used for 80 to 180 days, the shortest time in the province Greater Poland, the longest in the province Pomeranian. Chloride deposition ranged from about $1500 \mathrm{mg} / \mathrm{m}^{2}$.day from November to January, after which it dropped to about $15 \mathrm{mg} / \mathrm{m}^{2} \cdot \mathrm{d}$ from March to October. An average deposition of chlorides during the exposure period ranged from $480 \mathrm{mg} / \mathrm{m}^{2} \cdot \mathrm{d}$ at the Dębe Wielkie stand to 283 at the Stryków site. For comparison, the average annual deposition of chlorides coming with atmospheric precipitation in 2015 varied from $1.4 \mathrm{mg} / \mathrm{m}^{2} \cdot \mathrm{d}$ in the Lodz province up to $2.8 \mathrm{mg} / \mathrm{m}^{2} \cdot \mathrm{d}$ in the Pomeranian province.

The next set of results is related to an evaluation of corrosion losses of steel, zinc and hotdip galvanized steel (table 1). The mass loss of exposed samples is the basis for a determination of atmosphere corrosivity at each of 19 test sites. Regarding steel, the corrosivity category of $\mathrm{C} 4$ was observed at 8 sites, while at the remaining ones the corrosivity corresponds to the $\mathrm{C} 3$ category. Corrosion losses outside roads calculated on the basis of environmental parameters are 2-4 times lower and ranged within the categories of $\mathrm{C} 2$ and C3. The latter is determined for Silesia and Myślenice. Zinc corrosion losses classified to category $\mathrm{C} 4$ occurred at two stations. In the remaining ones they corresponded to corrosivity category C3. In areas outside of roads, zinc corrosion losses are about $20-100 \%$ lower and correspond to the corrosivity category of $\mathrm{C} 2$. Corrosion losses of zinc coating on roadside stands are higher than zinc corrosion losses by a factor 1.35. Corrosion losses at the off-road areas are approximately $20-100 \%$ lower than on roads.

Table 1. Corrosion losses of steel, zinc and galvanized steel and resulted categories of corrosivity of atmosphere at corrosion sites.

\begin{tabular}{|c|c|c|c|c|c|c|}
\hline \multirow{2}{*}{ Province } & Stand & \multicolumn{2}{|c|}{ Zinc } & Zinc coating & \multicolumn{2}{c|}{ Steel } \\
\cline { 2 - 7 } & $\begin{array}{c}\text { Corr. } \\
\text { loss, } \\
{[\mu \mathrm{m}]}\end{array}$ & $\begin{array}{c}\text { Corrosion } \\
\text { category }\end{array}$ & $\begin{array}{c}\text { Corr. loss, } \\
{[\mu \mathrm{m}]}\end{array}$ & $\begin{array}{c}\text { Corr. } \\
\text { loss } \\
{[\mu \mathrm{m}]}\end{array}$ & $\begin{array}{c}\text { Corrosion } \\
\text { category }\end{array}$ \\
\hline $\begin{array}{c}\text { Warsaw, } \\
\text { Mazovian }\end{array}$ & S8/Powązkowska & 2,8 & $\mathrm{C} 4$ & 5,6 & 41 & $\mathrm{C} 3$ \\
\hline & Lomianki & 1,5 & $\mathrm{C} 3$ & 2,0 & 30 & $\mathrm{C} 3$ \\
\hline & Marki & 1,2 & $\mathrm{C} 3$ & 1,4 & 42 & $\mathrm{C} 3$ \\
\hline & Dębe Wielkie & 2,1 & $\mathrm{C} 4$ & 2,6 & 54 & $\mathrm{C} 4$ \\
\hline & Mysiadło & 1,2 & $\mathrm{C} 3$ & 1,8 & 50 & $\mathrm{C} 4$ \\
\hline & Stanisławie & 1,3 & $\mathrm{C} 3$ & 2,1 & 68 & $\mathrm{C} 4$ \\
\hline & Gdynia Port & 1,2 & $\mathrm{C} 3$ & 1,7 & 63 & $\mathrm{C} 4$ \\
\hline & Wielki Kack & 1,5 & $\mathrm{C} 3$ & 1,9 & 77 & $\mathrm{C} 4$ \\
\hline & Rumia & 1,6 & $\mathrm{C} 3$ & 2,0 & 46 & $\mathrm{C} 3$ \\
\hline Pomeranian & Kórnik & 1,1 & $\mathrm{C} 3$ & 1,6 & 48 & $\mathrm{C} 3$ \\
\hline & Stryków & 1,0 & $\mathrm{C} 3$ & 1,7 & 64 & $\mathrm{C} 4$ \\
\hline & Września & 1,3 & $\mathrm{C} 3$ & 1,6 & 57 & $\mathrm{C} 4$ \\
\hline & Nowy Tomyśl & 1,1 & $\mathrm{C} 3$ & 1,7 & 44 & $\mathrm{C} 3$ \\
\hline & Luboń & 1,2 & $\mathrm{C} 3$ & 1,3 & 29 & $\mathrm{C} 3$ \\
\hline & Poczesna & 1,7 & $\mathrm{C} 3$ & 2,5 & 53 & $\mathrm{C} 4$ \\
\hline & Sośnica/Gliwice & 1,7 & $\mathrm{C} 3$ & 2,1 & 44 & $\mathrm{C} 3$ \\
\hline & A4 & 0,9 & $\mathrm{C} 3$ & 2,2 & 24 & $\mathrm{C} 3$ \\
\hline & Myślenice & 1,3 & $\mathrm{C} 3$ & 1,5 & 42 & $\mathrm{C} 3$ \\
\hline & Lubień & 1,1 & $\mathrm{C} 3$ & 1,4 & 34 & $\mathrm{C} 3$ \\
\hline
\end{tabular}


Linear correlation coefficients $\mathrm{R}$ between the parameters describing the environment and corrosion losses of steel, zinc and zinc coatings for the sample size $\mathrm{N}=21$ are given in Table 2.

Table 2. The values of linear correlation coefficients $\mathrm{R}$ between parameters describing the environment and corrosion losses of steel, zinc and zinc coatings.

\begin{tabular}{|c|c|c|c|c|c|c|}
\hline & \multirow[t]{2}{*}{ Traffic intensity } & \multirow{2}{*}{$\begin{array}{c}\mathrm{NO}_{2} \\
\text { concentr. }\end{array}$} & \multicolumn{3}{|c|}{ Corrosion losses } & \multirow{2}{*}{$\begin{array}{c}\mathrm{Cl}^{-} \\
\text {deposition }\end{array}$} \\
\hline & & & Zinc & Zinc coating & Steel & \\
\hline Traffic intensity & 1,000 & 0,782 & 0,478 & 0,807 & $-0,125$ & 0,240 \\
\hline $\mathrm{NO}_{2}$ concentration & 0,782 & 1,000 & 0,256 & 0,234 & $-0,150$ & $-0,064$ \\
\hline $\mathrm{Cl}^{-}$deposition & 0,240 & $-0,064$ & 0,463 & 0,212 & $-0,028$ & 1,000 \\
\hline Zinc & 0,478 & 0,256 & 1,000 & 0,716 & 0,002 & 0,463 \\
\hline Zinc coating & 0,807 & 0,545 & 0,716 & 1,000 & $-0,197$ & 0,212 \\
\hline Steel & $-0,125$ & $-0,150$ & 0,002 & $-0,197$ & 1,000 & $-0,028$ \\
\hline
\end{tabular}

Correlation at the good level between corrosion losses of zinc and zinc coating and traffic as well as corrosion losses of zinc and chloride deposition is observed. On the other side, there is no good correlation between environmental parameters and corrosion losses of steel. It should be noted that the small sample size $(\mathrm{N}=21)$ does not guarantee of an obtainment of precise relation between analyzed parameters. The estimation error for this sample is $21 \%$ with the assumption of an infinite population.

In preliminary steps to model the dependence of operating and environmental parameters on zinc and zinc coating corrosion losses a trial of constructing certain dose - response functions was attempted taking into consideration the most significant parameter - traffic intensity(NR). Examples are shown in Table 3.

Table 3. The comparison of dose - response equations of corrosion losses of zinc and zinc coating and traffic intensity.

\begin{tabular}{|c|c|c|c|c|}
\hline Function & Dose-response & $\mathrm{R}^{2}$ & $\mathrm{p}$ & $\begin{array}{c}\text { Mallow's } \\
\mathrm{C}_{\mathrm{p}}\end{array}$ \\
\hline \multirow{2}{*}{$\begin{array}{c}\text { Corrosion loss of } \\
\mathrm{Zn}=\mathrm{f} \text { (traffic intensity- } \\
\text { NR) }\end{array}$} & $0,9532 \mathrm{exp}(7 \mathrm{E}-6 \mathrm{NR})$ & 0,4175 & 0,0007 & 4,6 \\
\cline { 2 - 5 } & $(1 \mathrm{E}-5) \mathrm{NR}+0,7738$ & 0,5211 & 0,0000 & 3,7 \\
\cline { 2 - 5 } & $-0,3276+0,3671 \operatorname{logNR}$ & 0,3329 & 0,001 & 4,0 \\
\hline $\begin{array}{c}\text { Corrosion loss of zinc } \\
\text { coating } \\
\text { PC=f(traffic intensity NR) }\end{array}$ & $0,8117+(2,625 \mathrm{E}-5) \mathrm{NR}$ & 0,4960 & 0,0008 & 3,4 \\
\cline { 2 - 5 } & $1,3265 \exp (7,7112 \mathrm{E}-6 \mathrm{NR})$ & 0,4827 & 0,0008 & 3,6 \\
\hline $\begin{array}{c}\text { Corrosion loss of } \\
\mathrm{Zn}+\mathrm{PC}=\mathrm{f}(\text { traffic intensity } \\
\text { NR) }\end{array}$ & $0,6719+(2 \mathrm{E}-5) \mathrm{NR}$ & 0,4242 & 0,0008 & 5,25 \\
\hline
\end{tabular}

Elimination of some variables from the model results in a greater or lesser bias on the estimators of regression coefficients [8]. It depends on the size of the contribution that a given variable brings to the equation. The criterion which takes into account the impact of variables introduced to the model is the Cp Mallow's statistics, defined as follows [9]:

$$
C_{p}=\frac{R S S}{\sigma^{2}}-n+2 P
$$


where:

$R S S$ - sum of residual squares,

$\sigma^{2}$ - mean square of residuals, calculated from the equation containing all variables (it is assumed to be an unbiased estimate of the error expressed by the variance $\sigma^{2}$ ),

$P$ - the number of parameters (excluding an intercept),

$n$ - number of observations.

From the data presented in Table 3 it can be concluded that the linear and exponential functions better than the logarithmic describe the effect of traffic intensity on corrosion losses. The differences in the coefficients of determination are small, although the value of $p$ $<0.05$ indicates their significance. The smallest values of the Cp Mallow's statistics show a slightly better representation of the relationship for linear equation both in the modeling of zinc corrosion losses of zinc as well as zinc coating.

Two factors affect an uncertainty in the choice of function: small sample size and failure to consider other significant environmental parameters in the impact on corrosion losses. Other environmental parameters are primarily the wind speed and its direction, type of vehicles, fuel and vehicles velocity that increase an emission of gases, including $\mathrm{NO}_{2}$. A work to consider as many relevant environmental parameters as possible on the corrosion rate of structural metals will be continued.

\section{Conclusions}

1. The corrosiveness of the atmosphere in the immediate vicinity of roads and highways is at least one category higher in relation to zinc, and two, in relation to steel. This affects about twice as fast the corrosion rate of zinc and zinc coating in the area of roads compared to off-road areas.

2. The main source of increased corrosiveness of the atmosphere along the roads is traffic intensity, especially for the main protective materials for the road infrastructure i.e. zinc and zinc coating. This factor generates nitrogen oxides and the number of other compounds that are not always identifiable in every place or not always considered from the corrosion point of view for example wind speed and direction of wind. The effect of the object's distance from the road's edge in the plane and height was also observed.

3. The first attempts to model the dependence of operating and environmental parameters on zinc and zinc coating corrosion losses are not yet fully satisfactory at present, but there is a significant correlation between zinc and zinc coating corrosion losses as a function of traffic intensity.

This work was supported in part by the National Centre for Research and Development and General Directorate for National Roads and Motorways - research programme „The Development of Road Innovations, project RID 3B (agreement nr TZP/RID-I-64/12/NCBR/2016) NCBiR and GDDKiA in the frame of LifeRose Project.

\section{References}

1. J. Kobus, L. Kwiatkowski, R. Lutze, J. Jamroz, Identification and analysis of factors affecting the durability of steel road safety equipment, MATEC Web Conf. 122 pp. 02007 (2017). doi:10.1051/matecconf/201712202007

2. The contribution of inorganic and organic compounds released from transport. Report - 2013 (Instytut Ochrony Środowiska - Państwowy Instytut Badawczy, 2015)

3. ISO 9223:2012, Corrosion of metals and alloys - Corrosivity of atmospheres - 
Classification, determination and estimation (2012)

4. ISO 9224:2012, Corrosion of metals and alloys - Corrosivity of atmospheres-Guiding values for the corrosivity categories (2012)

5. ISO 9225:2012, Corrosion of metals and alloys - Corrosivity of atmospheresMeasurement of environmental parameters affecting corrosivity of atmospheres (2012)

6. ISO 9226:2012, Corrosion of metals and alloys - Corrosivity of atmospheres -Determination of corrosion rate of standard specimens for the evaluation of corrosivity (2012)

7. Air Quality Monitoring. Diffusive \& Passive Sampling. Available online: http://www.diffusivesampling.ivl.se/download/18.75d7780712240e747ea80009563/ (Swedish Environmental Research Institute, 2018)

8. R. Zieliński, Wybrane zagadnienia optymalizacji statystycznej (PWN, Warsaw, 1982)

9. A. Stanisz, Przystępny kurs statystyki z zastosowaniem STATISTICA PL na przykładach z medycyny. Tom 2. Modele liniowe i nieliniowe (StatSoft Poland, Cracow, 2007) 